Криворізький педагогічний інститут ДВНЗ «Криворізький наџіональний університет»

\title{
ПІДГОТОВКА МАЙБУТНІХ УЧИТЕЛІВ ПОЧАТКОВОЇ ШКОЛИ ДО ОРГАНІЗАЦЇ̈ ГРУПОВОЇ ФОРМИ НАВЧАННЯ УЧНІВ
}

У статті порушено питання підготовки майбутніх учителів початкової школи до організації групової форми навчання учнів, розглянуто форми і види групової роботи за різними критеріями.

Ключові слова: групова форма роботи, організачія групової роботи, моделі співпраці в групах, професійна підготовка вчителя.

В статье затронут вопрос подготовки будущего учителя начальной икольл к организации групповой формьл обучения школьников, рассмотрены формыл и виды групповой работы по разным критериям.

Ключевые слова: групповая форма работы, организачия групповой работы, модели сотрудничества в группах, профессиональная подготовка учителя.

The question of the future teacher training of primary schools for the organization of group studying of pupils, forms and types of group working according to different criteria are under consideration in this article.

Key words: form of group working, organization of group form of working, models of cooperation in groups, professional teacher training.

Важливість суспільної ролі вчителя зумовлена тим, що освіта - це єдиний соціальний інститут, через який проходить кожна людина, набуваючи рис особистості, фахівця і громадянина. Завдяки діяльності вчителя реалізується державна політика у створенні інтелектуального, духовного потенціалу нації, розвитку вітчизняної науки, техніки і культури на рівні світових досягнень, у збереженні й примноженні культурної спадщини й формуванні людини майбутнього [3, с. 89].

Нагальним завданням сьогодення є створення в Україні єдиної системи безперервної педагогічної освіти, у структурі якої має бути передбачено багаторівневість підготовки вчителя початкових класів: низова ланка - педагогічний коледж (готує молодших спеціалістів - учителів початкових класів); середня - педагогічний інститут (випускає бакалаврівучителів початкових класів зі спеціалізацією «Педагогіка» або «Психологія») і найвища ланка - педагогічний університет (готує магістрів педагогіки й психології) [6, с. 104]. 
Mema cmammi - розкрити специфіку підготовки майбутніх учителів початкової школи до організації групової форми навчання учнів.

Нині у зв'язку з реформами, що відбуваються в освітньому просторі, зростає необхідність модернізації концепції початкової освіти, посилюються вимоги до особистості педагога та його професійних якостей. Якісна професійна підготовка майбутніх учителів початкових класів потребує нових підходів до питань формування їх методичної готовності та компетентності.

На перший план висувається завдання навчання дітей 3 урахуванням індивідуальних особливостей їхнього розвитку. Реалізація цієї мети неможлива без досконалого знання вчителем інтелектуальних і особистісних особливостей кожного учня. Саме чіткі уявлення про індивідуальні особливості учнів допомагають учителю зробити навчальний процес спрямованим на розвиток здібностей кожної дитини. Основою професіоналізму вчителя на сучасному етапі $\epsilon$ його вміння $\mathrm{i}$ готовність прийняти учнів такими, які вони є, з їхніми індивідуальними особливостями [4, с. 30].

У процесі навчання вчитель повинен вміти слухати і чути кожного учня, розуміти і бачити його внутрішні спонукання i прагнення, спрямованість його потреб та інтересів. Педагогу потрібно знати і застосовувати на практиці педагогічні методи і прийоми, сприяючи швидкому долученню дитини до навчальної діяльності, загальному іiі розвитку і збереженню здоров'я [5, с. 10].

Педагог початкової школи зобов'язаний організовувати роботу 3 класом і систематично вправляти учнів у пошуку засобів забезпечення їх максимальної самореалізації інтелектуального та творчого потенціалу без збільшення емоційного напруження для інших. У процесі навчальної діяльності, як свідчать дані досліджень, творчі педагоги частіше наголошують на позитивних рисах учнів, які забезпечують виявлення творчого потенціалу через їх стійкість у досягненні результату, їх працелюбність, організованість поведінки та почуття честі.

Навчальна діяльність потребує від учня бути долученим до вирішення загальних завдань, які дає педагог на уроці, а також до групового спілкування, діалогу з класом. У масштабах групового спілкування засвоєння знань відбувається в учнів більш успішно. У цьому процесі індивідуальні зусилля 
кожної особистості об'єднуються і при правильному керівництві педагога швидше $\mathrm{i}$ точніше спрямовуються на розв'язання навчального завдання, що в результаті дає «груповий ефект».

Одним із дієвих засобів формування вміння вчитися, створення оптимальних умов для розвитку особистості $є$ навчальна діяльність учнів у групах, за якої кожен учасник робить унікальний вклад у спільну навчальну діяльність, а його зусилля потрібні й незамінні для загального успіху.

Аналіз наукових досліджень 3 проблеми показав важливість використання групової роботи в навчально-виховному процесі загальноосвітніх навчальних закладів, зокрема для підвищення індивідуалізації, самостійності, успішності навчання (О. Г. Ярошенко, Н. А. Мірошниченко, Г. А. Цукерман). $Є$ розробки загальних принципів організації групової навчальної діяльності (С. Френе, Х. Й. Лійметс, І. М. Чередов, М. Д. Виноградова, І. Б. Первін), описано форми й види групової роботи (I. М. Чередов, I. Е. Унт, I. Б. Первін, Н. С. Мойсенюк, Х. Й. Лейметс, О. І. Пометун, С. А. Полетило, О. В. Овчарук, О. Г. Ярошенко та ін.) [7, c. 55].

У науковій літературі спостерігається неоднорідність підходів до окреслення терміна «групова робота». Однією 3 причин цього $\epsilon$ наявність різних трактувань понять «форма організації навчання» (способів організації процесу навчання) та «форма навчальної діяльності учнів» (колективного або індивідуального характеру взаємодії між школярами у процесі навчання). Зокрема колективну та індивідуальну форми навчальної діяльності учнів можна реалізувати порізному: колективну - в умовах групової або фронтальної роботи, індивідуальну - індивідуальної, групової або фронтальної роботи (Ю. І. Мальований). Отже, в груповій роботі учнів можна використовувати колективну та індивідуальну форми навчальної діяльності. Перша форма роботи передбачає лише спільні зусилля учнів груп виконати поставлені завдання - спільне планування та виконання роботи, взаємоконтроль і взаємооцінювання; друга - організацію групової роботи школярів 3 переважанням індивідуальної діяльності (після розподілу доручень кожен учень виконує свою частину навчального завдання самостійно). Але співпраця в групах не може складатися лише 3 індивідуальної роботи, а неодмінно 
має містити певну частину колективної - розподіл доручень, взаємоперевірку, взаємооцінювання тощо.

Надзвичайно важливим для розуміння сутності групової роботи, на нашу думку, є твердження науковців про те, що групова навчальна діяльність - це організована вчителем спільна навчальна діяльність учнів одного класу, під час якої група (а не окремий учень) отримує завдання, виконання яких потребує спільних зусиль учнів - спільного планування роботи, взаємодопомоги, співробітництва, самооцінювання. Виконувати навчальні завдання учні можуть лише спільно або індивідуально. Кінцевий продукт групової роботи - це не механічне об'єднання окремих зусиль - суми результатів членів групи, а якісно новий результат завдяки вияву групового ефекту - результату, збагаченого колективними зусиллями думки й різноманітними почуттями.

Зважаючи на те, що різні форми й види групової роботи використовують для розширення й поглиблення знань сильних учнів та подолання неуспішності або відставання в навчанні слабких, групову роботу можна застосовувати на різних етапах різних типів уроків - під час перевірки домашніх завдань, вивчення нового матеріалу, закріплення вивченого матеріалу, відпрацювання знань і формування навичок, перевірки якості вивченого матеріалу.

Найбільші можливості відкриваються перед груповою навчальною діяльністю на етапах закріплення, поглиблення, систематизації знань. Навчання у складі груп дозволяє учням за короткий час актуалізувати теоретичний матеріал, оперативно здійснювати перевірку рівня його засвоєння кожним членом групи. Крім обліку знань, така перевірка одночасно $\epsilon$ і засобом їх систематизації, а також формування адекватної самооцінки результатів навчання $[1$, с. 10$]$.

Слід пам’ятати про те, що групова діяльність не позбавлена слабких сторін. За неправильного керівництва діяльність груп не виключено, що поставлені перед ними завдання можуть виконуватися найбільш здібними в групах учнями. Групове рішення може бути нераціональним за рахунок думки меншості, тобто сильних учнів без участі членів групи з середніми та слабкими навчальними можливостями. Групова діяльність потребує більше часу, ніж індивідуальна робота. В iii умовах не враховується і такий фактор, як різниця в темпі роботи кожного члена групи, в саморегуляції тощо. Досвід 
свідчить, що вчителі в два рази рідше запитують слабших учнів, щоб зекономити на уроці час.

Для подолання недоліків окремо взятих форм навчальної діяльності учнів доцільно оптимально поєднувати на уроці та в системі уроків різноманітні форми їхньої роботи [2, с. 125].

На нашу думку, в навчально-виховному процесі сучасної школи доцільно використовувати такі моделі співпраці: спільно-навчаючу, спільно-контролюючу, спільно-рівноправну, спільно-індивідуальну та комбіновану. Вибір форм або видів групової роботи для використання в навчально-виховному процесі залежить від специфіки класу та особливостей навчального матеріалу.

Групова творча діяльність у школі передбачає сумісну навчальну діяльність, визначається складом іiі учасників (рисами особистості, високим рівнем готовності до творчості й співпраці з іншими людьми, інтересами, працездатністю і творчими досягненнями), характером завдань, стратегією стосунків учасників. В умовах групової діяльності зростає прагнення до змагання в більшості учасників. Сама по собі групова діяльність характеризується певним репертуаром ролей, якими діти оволодівають по-різному.

Отже, для розвитку творчої особистості в школі потрібні творчі педагоги, які повинні розуміти механізми згоди, створити довірливе спілкування, мають правильно використовувати процедурні аспекти своєї діяльності в дискусії: вислуховувати учня, ставити запитання для уточнення протиріч, стимулювати виступи, аналізувати аргументи, позицію диспутанта, створювати позитивний мікроклімат у суперечці.

\section{Література}

1. Агрикова О. С. Групова форма організації навчальної діяльності школярів як спосіб реалізації особистісно-орієнтованого навчання / О. С. Агрикова, С. М. Муженко // Шкільний журнал. 2006. - №1-2. - С. 10-11. 2. Бондар В. І. Дидактика / Володимир Іванович Бондар. - К. : Либідь, 2005. - 264 с. 3. Володько В. М. Основні проблеми підготовки майбутнього вчителя / В. М. Володько // Педагогіка і психологія. - 1999. - №2 (23). С. 89-98. 4. Ільман В. Деякі аспекти вдосконалення професійної підготовки вчителя початкової школи: сучасні тенденції / Вікторія Ільман // Рідна школа. - 2011. - №1-2. - С. 30-32. 5. Полякова Г. Розвиток творчого потенціалу учнів засобами групової роботи на уроці / Г. Полякова // Психолог. - 2006. - №13. - С. 10-12. 6. Хомич Л. О. Система психолого-педагогічної підготовки вчителя початкових класів / Л. О. Хомич // Педагогіка і психологія. - 
1999. - №1 (22). - С. 104-110. 7. Шевчук Л. М. Форми й види групової роботи учнів / Л. М. Шевчук // Педагогіка і психологія. 2011. - №2 (71). - C. 54-62.

\section{РИТОРИЧНІ ВПРАВИ НА УРОКАХ УКРАЇНСЬКӦ̈ МОВИ В СТАРШИХ КЛАСАХ}

У статті розглянуто класифікації вправ з риторики, спрямовані на розвиток риторичних умінь і навичок. На їх основі автор пропонує оптимальну класифікацію вправ, щчо сприяє успішному засвоєнню риторичних знань на уроках мови.

Ключові слова: риторика, класифікація вправ, риторичні уміння і навички; підготовчі, тренувальні, підсумкові вправи.

В статье рассматриваются классификации упражнений по риторике, направленные на развитие риторических умений и навыков. На их основе автор предлагает оптимальную классификацию упражнений, которая способствует успешному усвоению риторических знаний на уроках языка.

Ключевые слова: риторика, классификачия упражнений, риторические умения и навыки; подготовительные, тренировочные, итоговые упражнения.

The article considers the existing methods of teaching the language classification exercises in rhetoric, that is directed on the development of the necessary rhetorical abilities and skills, based on them, the author offers the optimal system of exercises, which contributes to successful absorption of rhetorical knowledge of the language lessons.

Key words: rhetoric, classification of exercises, rhetorical abilities and skills; preparatory, training, final exercises.

У сучасних умовах розвитку шкільної освіти особливої актуальності набуває проблема формування в учнів риторичних умінь і навичок та застосування їх у різних сферах повсякденного життя.

Важлива роль у розв'язанні цієї проблеми належить вправам, оскільки вони дають змогу розвивати, зміцнювати і закріплювати необхідні риторичні навички, уміння, розв’язувати проблемні ситуації, збагачувати й використовувати нові знання з риторики. Академік О. Текучов зазначав, що «без вправ заняття звелися б до голої теорії», оскільки 